\title{
Emodin potentiates the antitumor effects of gemcitabine in pancreatic cancer cells via inhibition of nuclear factor- $k B$
}

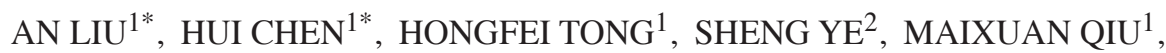 \\ ZHAOHONG WANG ${ }^{1}$, WEI TAN ${ }^{1}$, JINXIANG LIU ${ }^{1}$ and SHENGZHANG LIN ${ }^{1}$ \\ ${ }^{1}$ Department of Surgery, The Second Affiliated Hospital of Wenzhou Medical College, Wenzhou 325027; \\ ${ }^{2}$ The First Affiliated Hospital of Wenzhou Medical College, Wenzhou 325000, P.R. China
}

Received September 28, 2010; Accepted December 24, 2010

DOI: $10.3892 / \mathrm{mmr} .2011 .414$

\begin{abstract}
Many studies have demonstrated that emodin inhibits the growth and induces the apoptosis and chemosensitization of various cancer cells in animal models. The aim of this study was to investigate the molecular mechanism of the chemo-sensitization potential of emodin on gemcitabine in pancreatic cancer cell lines via inhibition of nuclear

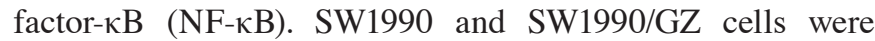
treated with: i) emodin $(20 \mu \mathrm{mol} / \mathrm{l})$, ii) $\mathrm{NF}-\kappa \mathrm{B}$ inhibitor Bay 11-7082 (5 $\mu \mathrm{mol} / \mathrm{l})$, iii) gemcitabine $(20 \mu \mathrm{mol} / \mathrm{l})$, iv) pretreated with emodin for $24 \mathrm{~h}$ followed by coincubation with gemcitabine for $24 \mathrm{~h}$, or v) pre-treated with Bay 11-7082 for $1 \mathrm{~h}$ followed by treatment with gemcitabine for $24 \mathrm{~h}$. SW1990 and SW1990/GZ cells were also treated with emodin (20, 40 and $80 \mu \mathrm{mol} / \mathrm{l})$. Cellular proliferation and apoptosis were detected by the Cell Counting Kit-8 (CCK-8) assay and flow cytometry. NF- $\kappa \mathrm{B}$ protein was detected by Western blotting. SW1990/GZ cell morphological changes were observed under optical and fluorescence microscopes. Emodin strongly inhibited the proliferation and induced the apoptosis of both pancreatic cancer cell lines. Furthermore, emodin combined with gemcitabine induced a higher percentage of growth inhibition and apoptosis in both pancreatic cancer cell lines compared to gemcitabine alone. Pre-treatment of SW1990/ GZ cells with Bay 11-7082 for $1 \mathrm{~h}$ followed by gemcitabine resulted in greater inhibitory and apoptosis rates compared to gemcitabine alone. The resistant pancreatic cell line SW1990/ GZ presented higher constitutive $\mathrm{NF}-\kappa \mathrm{B}$ protein expression compared to the SW1990 cells. Emodin not only downregulated $\mathrm{NF}-\kappa \mathrm{B}$ in a dose-dependent manner in SW1990 and SW1990/GZ cells under unstimulated conditions, but also
\end{abstract}

Correspondence to: Dr Shengzhang Lin, The Second Affiliated Hospital and Yuying Children's Hospital of Wenzhou Medical College, 109 West Xue-yuan Road, Wenzhou 325027, P.R. China E-mail:wzf21sz@163.com

${ }^{*}$ Contributed equally

Key words: emodin, nuclear factor- $\kappa \mathrm{B}$, gemcitabine, pancreatic cancer inhibited gemcitabine-induced $\mathrm{NF}-\kappa \mathrm{B}$ protein expression. Emodin potentiated the antitumor effects of gemcitabine in pancreatic cancer, which was related to the down-regulation of $\mathrm{NF}-\kappa \mathrm{B}$.

\section{Introduction}

Currently, gemcitabine remains the best chemotherapeutic agent available for the treatment of advanced pancreatic cancer. However, the treatment still results in an objective tumor response rate of less than $10 \%$, with a dismal survival advantage accompanied by multiple adverse effects and drug resistance (1). Thus, a less toxic agent that is capable of sensitizing pancreatic cancer cells to gemcitabine is required.

Emodin (1,3,8-trihydroxy-6-methylanthraquinone) is an active constituent isolated from the root of Rheum palmatum $L$. (2) and is the main effective component of herbs such as rhubarb and aloe. Pharmacological studies have demonstrated that emodin possesses anti-bacterial (3), anti-inflammatory (4) and immunosuppressive (5) effects. In the context of cancer, recent studies show that emodin exhibits an anti-proliferative effect on cell lines derived from ovarian cancer (6), lung cancer (7) and leukemia (8). Additionally, emodin has been reported to suppress the growth of multidrug-resistant prostate cancer cells (9) through the activation of Akt (10), to inhibit tumor migration (11) and to induce apoptosis in tumor cells by suppressing nuclear factor- $\kappa \mathrm{B}(\mathrm{NF}-\kappa \mathrm{B})(12)$.

The transcription $\mathrm{NF}-\kappa \mathrm{B}$ has been linked to cell proliferation, invasion, angiogenesis, metastasis and the suppression of apoptosis in pancreatic cancer (13-16). Many conventional cancer chemotherapeutic agents, such as gemcitabine, vinblastine, vincristine, daunomycin, doxorubicin, campothecin, cisplatin and etoposide, have been shown to activate $N F-\kappa B$ $(13,14,16,17)$. There are numerous lines of evidence suggesting that $\mathrm{NF}-\kappa \mathrm{B}$ plays a major role in the growth and chemo -resistance of pancreatic cancer $(12,18)$. NF- $\kappa \mathrm{B}$ is constitutively active in pancreatic cancer cells (18), animal models of pancreatic cancer $(6,7)$ and human pancreatic cancer tissues (18), but not in immortalized, non-tumorigenic pancreatic ductal epithelial cells (19). NF- $\kappa \mathrm{B}$ promotes pancreatic cancer growth via the inhibition of apoptosis $(18,20)$. Additionally, $\mathrm{NF}-\kappa \mathrm{B}-$ regulated gene products promote the migration and invasion of cancer cells (15), and $\mathrm{NF}-\kappa \mathrm{B}$ may play a pivotal 
role in promoting gemcitabine resistance in pancreatic cancer (21). These findings implicate $\mathrm{NF}-\kappa \mathrm{B}$ in pancreatic cancer, and suggest that agents blocking $\mathrm{NF}-\kappa \mathrm{B}$ activation may reduce chemoresistance to gemcitabine and perhaps be used in combination with gemcitabine as a novel therapeutic regimen for pancreatic cancer.

In the present study, we investigated the role of $\mathrm{NF}-\kappa \mathrm{B}$ in the molecular mechanisms of the chemo-sensitization potential of emodin on gemcitabine in pancreatic cancer cell lines.

\section{Materials and methods}

Reagents. Emodin was purchased from Sigma (St. Louis, MO, USA) and dissolved in dimethylsulfoxide (DMSO) to make $0.2 \mathrm{mmol} / 1$ stock solution. Gemcitabine was purchased from Ely Lilly (Bad Homburg, Germany) and dissolved in sterile $0.9 \%$ sodiumchloride to make a $50 \mathrm{~g} / 1$ stock solution. The final concentration of DMSO was $<0.1 \%$. DAPI (4',6-diamidino-2phenylindole) and BAY 11-7082 were purchased from Sigma. Antibodies against p65 $(\mathrm{NF}-\kappa \mathrm{B})$ and $\beta$-actin were obtained from Epitomics (Burlingame, CA, USA).

Cell culture. The human pancreatic cancer cell line SW1990 was purchased from the American Type Culture Collection (Manassas, VA, USA). The cell line was maintained in a state of continuous exponential growth in RPMI-1640 (Gibco BRL, Grand Island, NY, USA) supplemented with $10 \%$ fetal bovine serum (FBS) (Gibco BRL), $100 \mathrm{U} / \mathrm{ml}$ penicillin and $10 \mu \mathrm{g} / \mathrm{ml}$ streptomycin in a humidified incubator containing $5 \% \mathrm{CO}_{2}$ in air at $37^{\circ} \mathrm{C}$.

Establishment of gemcitabine-resistant pancreatic cancer cells. A gemcitabine-resistant pancreatic cancer cell line (SW1990/GZ) was established by serially escalating doses of gemcitabine in SW1990 cells (22). Initially, cells were cultured for $72 \mathrm{~h}$ with gemcitabine $(10 \mathrm{nmol} / \mathrm{l})$ with a defined drugfree interval. As cells adapted to the dose, the gemcitabine concentration was serially doubled. By the end of the culture, SW1990 cells were adapted to $100 \mathrm{nmol} / 1$ gemcitabine.

Observation of morphological changes. Morphological changes in SW1990/GZ cells were observed under an optimal microscope (Olympus, Tokyo, Japan) after treatment. Apoptotic cells were identified by DAPI staining. SW1990/ GZ cells were seeded on coverslips and, after treatment, were fixed with $4 \%$ paraformaldehyde in $0.1 \mathrm{M}$ PBS $(\mathrm{pH} 7.4)$ for $10 \mathrm{~min}$. After the nuclear DNA was stained with $1 \mu \mathrm{g} / \mathrm{ml}$ DAPI for another $5 \mathrm{~min}$, the cells were observed under an Olympus fluorescence microscope.

Inhibition of cell viability by emodin and gemcitabine. SW1990/GZ (resistant to gemcitabine) and SW1990 (sensitive to gemcitabine) cells were seeded at a density of $4 \times 10^{3}$ cells/ well in 96-well microtiter culture plates. After overnight incubation, the medium was removed and replaced with fresh medium containing emodin $(20 \mu \mathrm{mol} / \mathrm{l})$ for $24 \mathrm{~h}$, and then exposed to gemcitabine $(20 \mu \mathrm{mol} / \mathrm{l})$ for an additional $24 \mathrm{~h}$. Thus, for a single-agent treatment, cells were exposed to emodin for $24 \mathrm{~h}$ or gemcitabine for $24 \mathrm{~h}$. On completion of incubation, cell viability was determined by the CCK- 8 assay
(Beyotime, Shanghai, China) according to the manufacturer's instructions. Briefly, CCK-8 solution was added to cells in 96-well plates, the cells were incubated at $37^{\circ} \mathrm{C}$ for $60-90 \mathrm{~min}$, and the optical density of each well was read at $450 \mathrm{~nm}$ using a microplate reader (ELX800; Bio-Tek, USA).

Cell viability inhibition by Bay 11-7082 and gemcitabine. Cells were plated as described above and allowed to attach overnight. The cells were replaced with fresh medium containing $5 \mu \mathrm{mol} / \mathrm{l}$ of Bay 11-7082 for $1 \mathrm{~h}$ and then exposed to $20 \mu \mathrm{mol} / \mathrm{l}$ of the chemotherapeutic agent, gemcitabine, for an additional $24 \mathrm{~h}$. Thus, for a single-agent treatment, cells were exposed to Bay 11-7082 for $1 \mathrm{~h}$. The effect of Bay 11-7082 pre-treatment on cell viability was examined by the CCK- 8 assay method as described above.

Flow cytometric assessment of apoptosis. The measurement of phosphatidylserine redistribution in the plasma membrane was conducted with the Annexin V-FITC/PI apoptosis detection kit according to the manufacturer's protocol (Abcam, Cambridge, MA, USA). After treatment, harvested cells $\left(1 \times 10^{5}\right)$ were suspended in $500 \mu \mathrm{l}$ of Annexin $\mathrm{V}$ binding buffer (1X). Annexin V-FITC $(5 \mu \mathrm{l})$ and PI $(5 \mu \mathrm{l})$ were added and incubated with the cells for $15 \mathrm{~min}$ in the dark. $1 \mathrm{X}$ binding buffer $(500 \mu \mathrm{l})$ was added to each sample. The stained cells were analyzed directly by flow cytometry using the Cell Quest program (Becton Dickinson, San Jose, CA, USA). The average of the results from at least three samples of cells for each experimental condition is presented.

Protein extraction and Western blot analysis. The pancreatic cancer cells SW1990/GZ and SW1990 were plated and allowed to attach for $36 \mathrm{~h}$. Emodin was directly added to cell cultures at a $20 \mu \mathrm{mol} / 1$ concentration and cells were incubated for $48 \mathrm{~h}$ followed by the addition of gemcitabine. Control cells were incubated in medium containing an equivalent concentration of EMSO. After $24 \mathrm{~h}$ of incubation with gemcitabine, the cells were harvested in PBS and whole cell lysate was prepared by suspending the cells in $200 \mu \mathrm{L}$ of lysis buffer $[1 \mathrm{~mol} / 1$ Tris- $\mathrm{HCl}(\mathrm{pH} 7.5), 150 \mathrm{mmol} / \mathrm{l} \mathrm{NaCl}, 1 \mathrm{mmol} / \mathrm{l}$ EGTA, 0.1\% Triton X-100, $0.1 \mathrm{mmol} / \mathrm{l}$ sodium orthovanadate, $1 \mathrm{mmol} / \mathrm{l}$ phenylmethylsulfonyl fluoride (PMSF), $2 \mu \mathrm{g} / \mathrm{ml}$ leupeptin and $2 \mu \mathrm{g} / \mathrm{ml}$ aprotinin]. The cells were disrupted by sonication and the total proteins were extracted by centrifuging the tubes at $4^{\circ} \mathrm{C}$ for $30 \mathrm{~min}$ at the maximal microfuge speed to remove debris. For immunoblotting, each extract was prepared as above and the equivalent of $20 \mu \mathrm{g}$ total proteins was separated on SDS-PAGE, electrotransferred onto nitrocellulose membranes and probed with specific antibodies. Detection of specific proteins was carried out with an enhanced chemiluminescence Western blot kit according to the manufacturer's instructions. The same membrane was reprobed with the anti$\beta$-actin antibody, which was used as an internal control for protein loading.

Statistical analysis. Data are represented as the mean \pm SD for the absolute values or as a percentage of the controls. SPSS 11.0 software was used for statistical analysis. ANOVA (analysis of variance) was applied for comparison of the means of two or multiple groups, in which SNK (Student-Newman- 

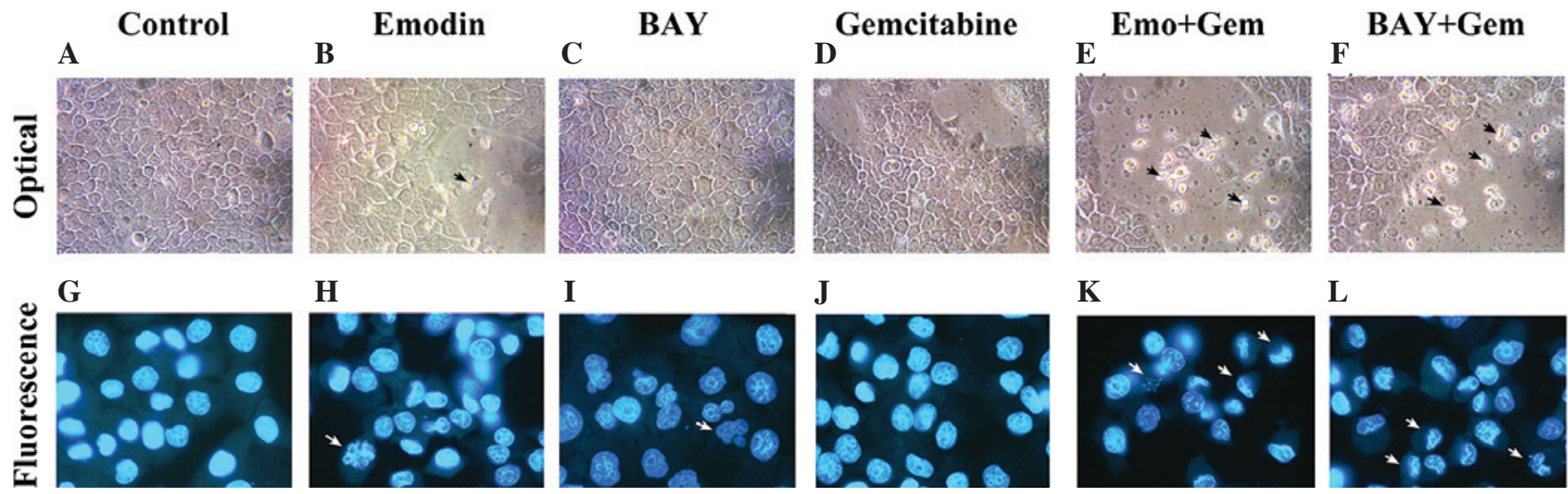

Figure 1. Morphological changes in the pancreatic cancer cell line SW1990/GZ. SW1990/GZ cells were treated with (A and G) 0.1\% of DMSO, (B and H) $20 \mu \mathrm{mol} / 1$ of emodin, (C and I) $5 \mu \mathrm{mol} / 1$ of Bay 11-7082, (D and J) $20 \mu \mathrm{mol} / 1$ of gemcitabine, (E and K) pre-treated with emodin for $24 \mathrm{~h}$ followed by coincubation with gemcitabine for $24 \mathrm{~h}$, (F and L) pre-treated with Bay 11-7082 for $1 \mathrm{~h}$ followed by coincubation with gemcitabine for $24 \mathrm{~h}$. Cells were visualized under an optimal microscope (A-F; x200) or fluorescence microscope (G-L; x400). Apoptotic cells were characterized by cellular shrinkage (arrows: B, E and F) or by nuclear condensation, chromatin margination and apoptotic bodies (arrows: H, I, K and L).

Kewls) was further used for the comparison of two groups. A value of $\mathrm{p}<0.05$ was considered significant.

\section{Results}

Morphological changes in pancreatic cells. Under an optimal microscope, control SW1990/GZ cells were well spread flatly and appeared spindly (Fig. 1A). Emodin (Fig. 1B) induced the appearance of many rounded SW1990/GZ cells and decreased cell density. After co-treatment of gemcitabine with emodin or Bay 11-7082 (Fig. 1E and F), cellular fragmentation was extensive and few adherent cells remained. In addition, nuclear morphological changes were observed under a fluorescence microscope by DAPI staining. The results showed that emodin with or without gemcitabine caused nuclear condensation and chromatin margination (Fig. $1 \mathrm{H}$ and $\mathrm{K}$ ).

Effect of emodin and gemcitabine on cell proliferation. To examine the effect of emodin on cell growth, pancreatic cancer SW1990 cells (sensitive to gemcitabine) and SW1990/GZ cells (resistant to gemcitabine) were treated with emodin $(20 \mu \mathrm{mol} / \mathrm{l})$ alone for 24 h. As shown in Fig. 2, in SW1990 and SW1990/GZ cells, treatment with emodin $(20 \mu \mathrm{mol} / \mathrm{l})$ alone for $24 \mathrm{~h}$ resulted in cell inhibition of 14 and $20 \%$ relative to control, respectively. Subsequently, the effect of gemcitabine on cell growth in vitro was evaluated. SW1990 cells were more sensitive to gemcitabine compared to SW1990/GZ cells. In SW1990 and SW1990/GZ cells, gemcitabine treatment $(20 \mu \mathrm{mol} / \mathrm{l})$ for $24 \mathrm{~h}$ reduced cell viability by 24 and $8 \%$, respectively, relative to the control. However, pre-treatment with emodin for $24 \mathrm{~h}$ followed by treatment with gemcitabine resulted in the loss of 34 and $36 \%$ of viable cells in the two cell lines.

Bay 11-7082 potentiates growth inhibition induced by gemcitabine. To assess the effect of pre-treatment with Bay 11-7082 $(5 \mu \mathrm{mol} / 1$ for $1 \mathrm{~h})$ followed by treatment with gemcitabine $(20 \mu \mathrm{mol} / 1$ for $24 \mathrm{~h})$ on cell viability, viable cells were evaluated by the CCK-8 assay. As shown in Fig. 2, treatment with Bay 11-7082 alone for $1 \mathrm{~h}$ resulted in only a 5 and $12 \%$ loss of viability of SW1990 and SW1990/GZ cells, respectively.

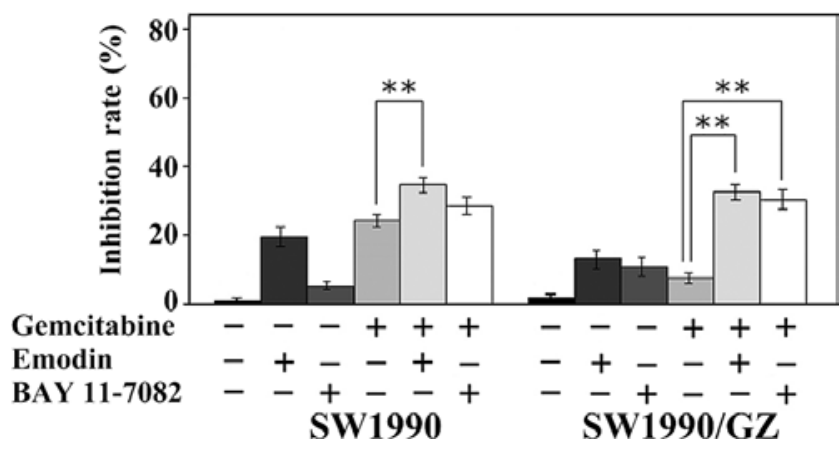

Figure 2. Evaluation of cell viability by CCK-8 assay. SW1990 and SW1990/ GZ cells were either untreated or treated with individual agents, or pre-treated with $20 \mu \mathrm{mol} / 1$ emodin or $5 \mu \mathrm{mol} / 1$ Bay $11-7082$ for 24 and $1 \mathrm{~h}$, respectively, followed by coincubation with $20 \mu \mathrm{mol} / 1$ gemcitabine for $24 \mathrm{~h}$. On termination of incubation, viable cells were evaluated relative to the untreated control and interpreted as the percentage of viable cells. Points, averages of three independent experiments. ${ }^{* *} \mathrm{p}<0.001$, statistical significance.

However, pre-treatment with Bay 11-7082 for $1 \mathrm{~h}$ followed by treatment with gemcitabine resulted in the loss of 28 and $30 \%$ of viable cells in the two cell lines.

Emodin and Bay 11-7082 sensitize cells to apoptosis induced by gemcitabine. The induction of apoptosis in pancreatic cancer cells treated with either emodin $(20 \mu \mathrm{mol} / \mathrm{l})$, gemcitabine $(20 \mu \mathrm{mol} / \mathrm{l})$ or Bay 11-7082 $(5 \mu \mathrm{mol} / \mathrm{l})$ alone was observed. Compared to the single agents, pre-treatment with emodin or Bay 11-7082 followed by gemcitabine treatment induced a greater degree of apoptosis in both the cell lines, as shown by a flow cytometric assay (Fig. 3), in particular in the cell line resistant to gemcitabine (SW1990/GZ).

Effect of emodin on $N F-\kappa B$ protein expression. To analyze the role of NF-kB in the growth of resistant cell line, protein extracted from untreated cells was prepared and Western blotting for NF- $\mathrm{KB}$ expression was performed. As shown in Fig. 4A, SW1990/GZ cells exhibited enhanced NF-KB protein expression compared to SW1990 cells. We then analyzed whether emodin abrogates the basal expression NF- $\mathrm{kB}$ in these cells. To 
A
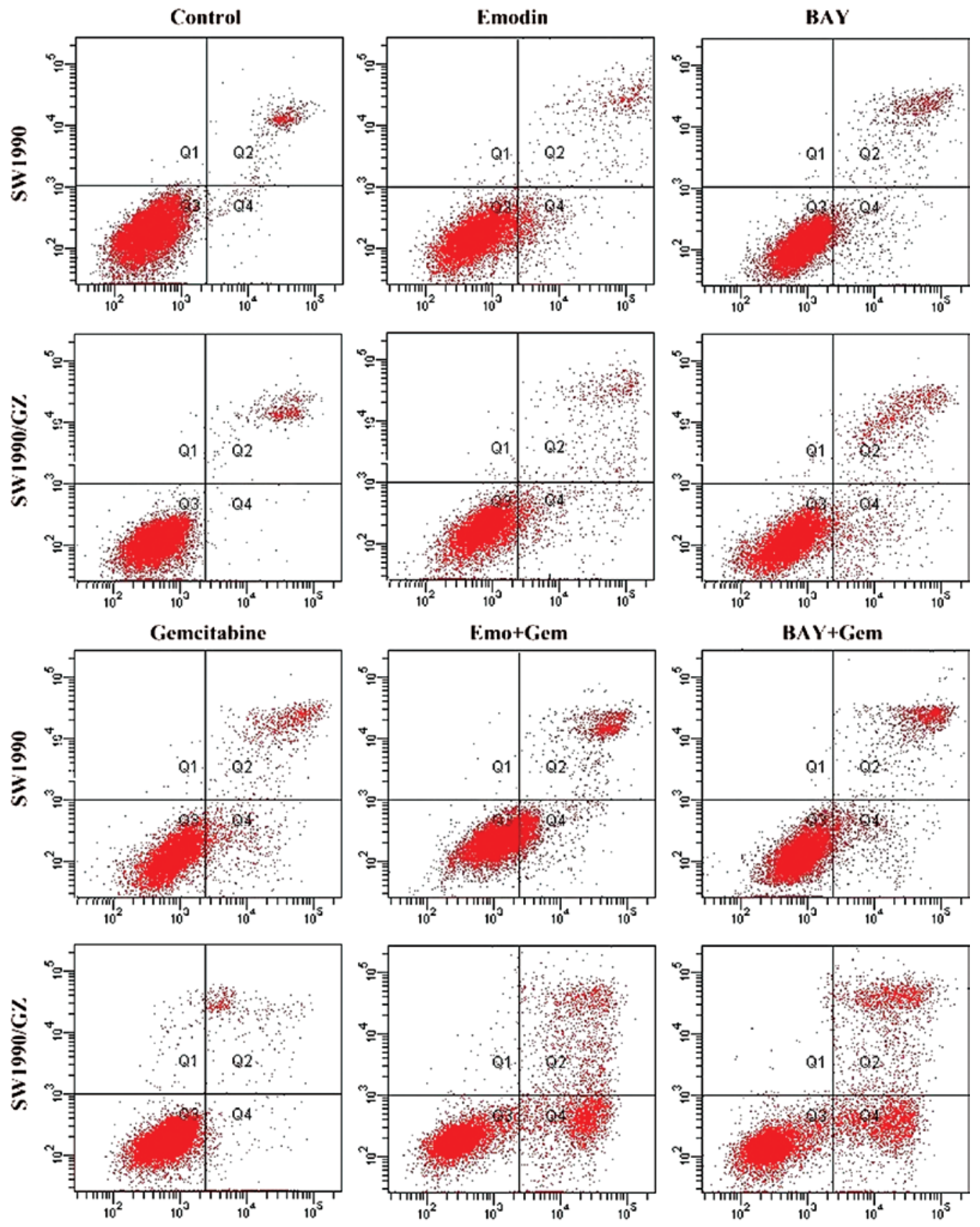

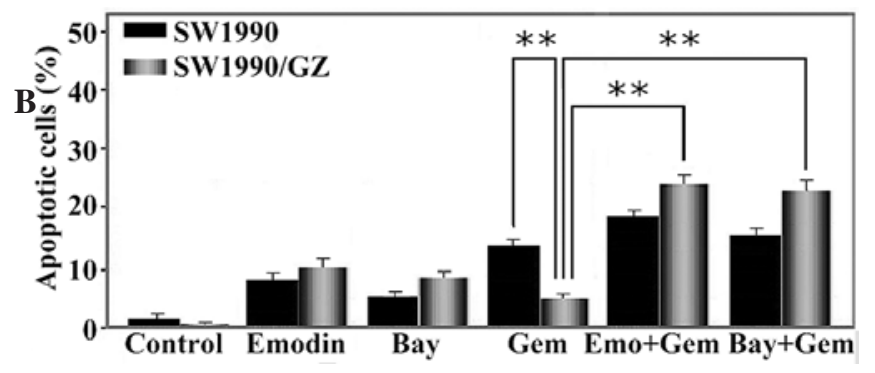

evaluate the effect of emodin in SW1990 and SW1990/GZ cells, semiconfluent cells were treated with varying concentrations $(0$, 20, 40 and $80 \mu \mathrm{mol} / \mathrm{l}$ ) of emodin for $72 \mathrm{~h}$. As shown in Fig. 4B, a dose-dependent decrease in NF- $\mathrm{KB}$ protein expression was observed after the cells were exposed to increasing concentrations of emodin. Even a low concentration of emodin $(20 \mu \mathrm{mol} / \mathrm{l})$ resulted in the inhibition of NF- $\mathrm{kB}$ protein expression.
Figure 3. (A) Apoptosis induced by emodin (20 $\mu \mathrm{mol} / \mathrm{l})$, Bay 11-7082 (5 $\mu \mathrm{mol} / 1)$ and gemcitabine $(20 \mu \mathrm{mol} / 1)$ alone or by co-treatment with gemcitabine plus emodin or Bay 11-7082. The cell death pattern of SW1990 and SW1990/GZ cell lines was assessed by qualitative flow cytometry using Annexin-V and propidium iodide. The lower left quadrant represents living cells; upper left, propidium iodide-positive; lower right, Annexin V-positive; upper right, both Annexin V-and propidium iodide-positive. The experiment was performed three times with similar results. (B) The percentage of apoptotic cells in each group. ${ }^{* *} \mathrm{p}<0.001$, statistical significance.

Effect of emodin combined with gemcitabine on NF- $\kappa B$ protein expression. We analyzed whether gemcitabine was capable of inducing NF- $\mathrm{KB}$ protein expression and whether the inactivation of NF- $\mathrm{KB}$ by emodin abrogated the chemoresistant phenotype of SW1990/GZ cells, resulting in more pronounced gemcitabine-induced apoptosis. Our results showed that, relative to the untreated control, gemcitabine $(20 \mu \mathrm{mol} / \mathrm{l})$ treatment induced NF-kB protein expression in SW1990 and SW1990/ 
A
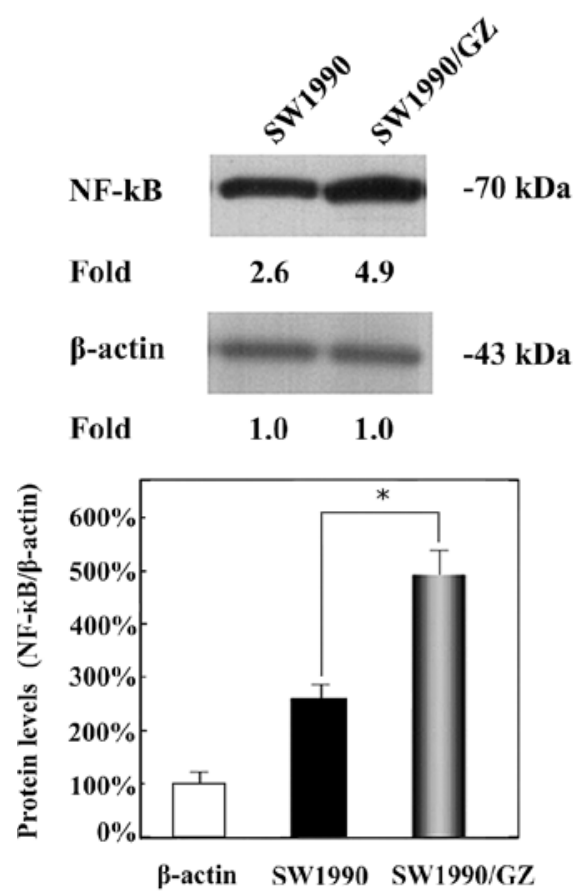

B

SW1990

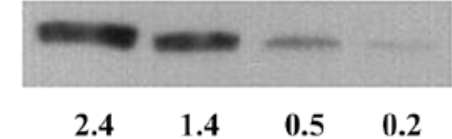

$-70 \mathrm{kDa}$

Fold

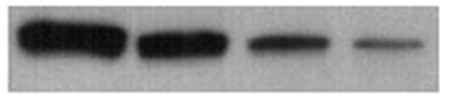

$-70 \mathrm{kDa}$

SW1990/GZ

$\begin{array}{lllll}5.2 & 3.6 & 1.8 & 0.7\end{array}$

Fold

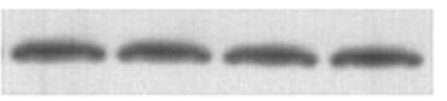

$-43 \mathrm{kDa}$

Fold

$\begin{array}{llll}1.0 & 1.0 & 1.0 & 1.0\end{array}$

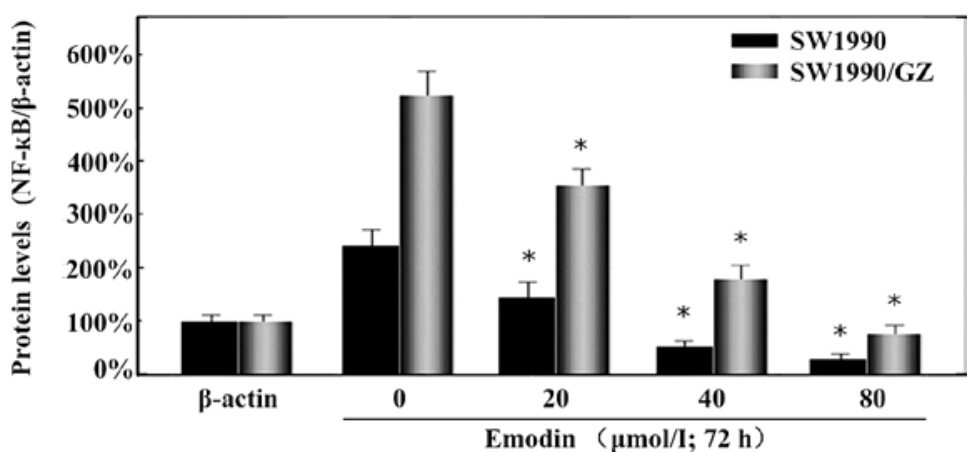

Figure 4. Down-regulation of NF-kB by emodin in the SW1990 and SW1990/GZ cell lines. (A) The level of NF-kB in SW1990 and SW1990/GZ cells determined by Western blot analysis. "p<0.001, SW1990/GZ vs. SW1990. (B) Dose-response by emodin in the down-regulation of NF- $\mathrm{kB}$ in SW1990 and SW1990/ GZ cells. Proteins were prepared from cells after incubation with a $20 \mu \mathrm{mol} / 1$ concentration of emodin for up to $72 \mathrm{~h}$. "p $<0.001$, compared to lower concentration of emodin.

GZ cells (Fig. 5). Furthermore, pre-treatment of the cells with $20 \mu \mathrm{mol} / \mathrm{l}$ emodin for $48 \mathrm{~h}$ abrogated the gemcitabine-induced activation of $\mathrm{NF}-\kappa \mathrm{B}$ protein expression.

\section{Discussion}

The loss of viability and induction of apoptotic cell death are two major mechanisms by which chemotherapeutic agents kill cancer cells. Unfortunately, in pancreatic tumors, the acquisition of drug resistance during chemotherapy constitutes a major impediment in curing patients. In a clinical setting, suboptimal therapeutic benefit was achieved when prognostic combinations of various classes of chemotherapeutic agents were administered, due to their dose-limiting toxicity (23). Extensive studies have demonstrated that the underlying resistance to therapeutic response and aggressiveness of pancreatic cancer cells are partly due to the constitutive activation of the transcription factor NF- $\mathrm{B}(13,14,16-21)$. In this study, we established the gemcitabine-resistant human pancreatic cancer cell line SW1990/GZ by exposure of cells to serially escalating doses of gemcitabine. The transcription factor NF- $\mathrm{B}$ B was constitutively expressed in the resistant and sensitive pancreatic cancer cell lines. The resistant cell line (SW1990/GZ) presented higher NF-кB expression than the sensitive cell line (SW1990). Since NF- $\kappa B$ activates the expression of antiapoptotic genes $(14,16,18,20)$, we suggest that the observed increase in $\mathrm{NF}-\kappa \mathrm{B}$ protein expression is connected with the acquisition of drug resistance, contributing to the survival of resistant cell lines. However, emodin significantly

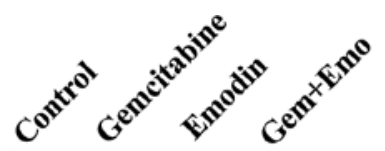

SW1990

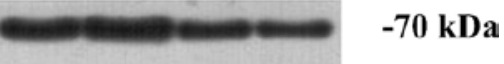

Fold

$\begin{array}{llll}2.6 & 3.4 & 2.1 & 1.8\end{array}$

SW1990/GZ

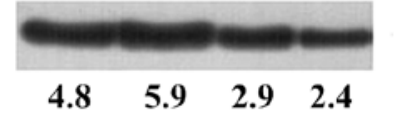

$-70 \mathrm{kDa}$

Flod

$\beta$-actin

$-43 \mathrm{kDa}$

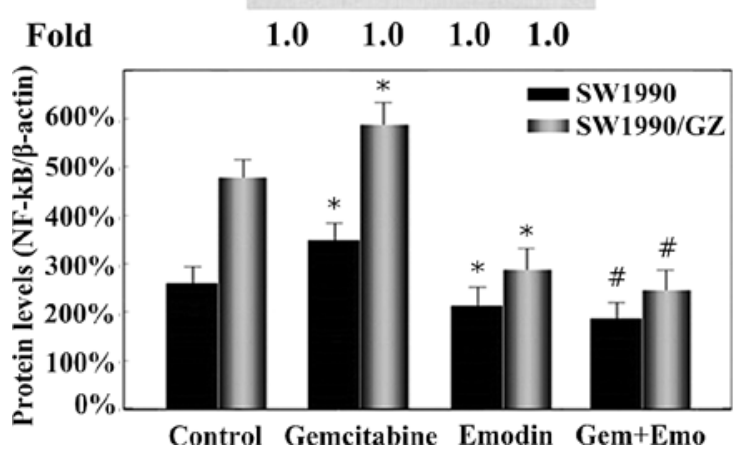

Figure 5. Western blotting of NF- $\kappa$ B protein expression in SW1990 and SW1990/GZ cell lines in the presence and/or absence of emodin. Lane 1, untreated control; lane 2, treated with gemcitabin $(20 \mu \mathrm{mol} / 1,48 \mathrm{~h})$; lane 3 , treated with emodin $(20 \mu \mathrm{mol} / 1,24 \mathrm{~h})$; lane 4 , emodin pre-treatment followed by coincubation with gemcitabine. $\beta$-actin served as a loading control. " $\mathrm{p}<0.001$, compared to control group; ${ }^{*} \mathrm{p}<0.001$ compared to control and gemcitabine groups. 
decreased cellular proliferation in the gemcitabine-sensitive and -resistant human pancreatic cancer cell lines, and both cell lines showed a high rate of apoptosis after emodin treatment. Furthermore, the results of Western blotting demonstrated that emodin down-regulated $\mathrm{NF}-\kappa \mathrm{B}$ protein expression in a dosedependent manner. Together, the results indicate that emodin was an effective inhibitor of pancreatic cancer cell growth as a single agent.

Bay 11-7082,(E)-3-(4-methylphenylsulfonyl)-2-propenenitrile, was initially identified as a irreversible inhibitor of $\kappa \mathrm{B}-\alpha$ phosphorylation that inhibits the $\mathrm{NF}-\kappa \mathrm{B}$ pathway. Further studies into alternative therapeutic strategies against malignancies have shown that this compound is a potent inducer of apoptosis in a number of malignant cells, including colorectal (24) and breast (25) cancer, as well as leukemia, myeloma cells and lymphoma cells (26). In the present study, we demonstrated that the inhibition of constitutive NF- $\kappa \mathrm{B}$ activity by Bay 11-7082 resulted in the growth inhibition and induction of apoptosis in both our pancreatic cancer cell lines. These results are in keeping with previous reports demonstrating that constitutive NF- $\kappa \mathrm{B}$ activity is associated with aggressive tumors, whereas its inhibition blocks the growth of these cells $(13-16,21)$. NF- $\mathrm{B}$ may therefore be essential for the survival of pancreatic cancer cells.

Several studies have reported that gemcitabine activates $\mathrm{NF}-\kappa \mathrm{B}(13,14,16,20)$ and MDR $(27)$. Our results also showed that gemcitabine enhanced $\mathrm{NF}-\kappa \mathrm{B}$ protein expression in both our pancreatic cancer cell lines. NF- $\kappa \mathrm{B}$ has also been shown to act upstream of human MDR-1 in colon cancer cells (28). $\mathrm{P}$-gp is encoded by the MDR-1 gene and is a broad spectrum multidrug efflux pump that recognizes various compounds, including antitumor drugs. However, emodin exerts a downregulatory effect on MDR-1 protein in prostate cells, with over-activated HIF-1 and potent MDR (9). In previous studies, emodin has been shown to synergize with cisplatin $(29,30)$, paclitaxel (6) and celecoxib (31), leading to an enhanced antiproliferation effect in several cancer cell lines. Therefore, we hypothesized that emodin combined with gemcitabine may also have a synergistic effect on pancreatic cancer cell proliferation and apoptosis. Supporting this hypothesis, the results presented here suggest that emodin pre-treatment led to significant tumor cell apoptosis compared to any of the agents alone in both the sensitive and resistant pancreatic cancer cell lines. This observation is of high significance, as $33-35 \%$ growth inhibition was achieved using a dose of gemcitabine that produces only 24 and 8\% growth inhibition in SW1990 and SW1990/GZ cell lines, respectively, when gemcitabine was used alone. The inhibition of cell growth was also correlated with apoptotic cell death, suggesting that the loss of viable cells with emodin and gemcitabine treatment is partly due to the induction of an apoptotic cell death mechanism.

The mechanism by which emodin potentiates the antiproliferative and apoptotic effects of gemcitabine may involve the suppression of $\mathrm{NF}-\kappa \mathrm{B}$. Both the pancreatic cancer cell lines studied showed constitutive $\mathrm{NF}-\kappa \mathrm{B}$ protein expression. Our results show that emodin not only down-regulated $\mathrm{NF}-\kappa \mathrm{B}$ protein expression under unstimulated conditions, but also inhibited gemcitabine-induced $\mathrm{NF}-\kappa \mathrm{B}$ protein expression in both our pancreatic cancer cell lines. These observations provide strong evidence that gemcitabine induced $\mathrm{NF}-\kappa \mathrm{B}$, and its down-regulation by emodin may be a common phenomenon in pancreatic cancer cells. Moreover, the anti-proliferative and apoptotic effects of treatment with Bay 11-7082 combined with gemcitabine on the two pancreatic cancer cell lines were similar to those observed with co-treatment of emodin plus gemcitabine. NF- $\mathrm{NB}$ has been linked to chemoresistance $(13,14,16-21)$, so it is very likely that the down-regulation of $\mathrm{NF}-\kappa \mathrm{B}$ by emodin sensitized the cells to gemcitabine. These results are in agreement with several previous reports in which curcumin (16), thymoquinone (14) and hyperthermia (13) sensitized pancreatic cancer cells to gemcitabine. Similarly, genistein has been shown to sensitize prostate cancer cells to gemcitabine through the down-regulation of NF- $\mathrm{B}$ (32).

In conclusion, our results showed that emodin potentiates the antitumor effects of gemcitabine by inhibiting NF- $\mathrm{B}$, and that the combination of emodin with gemcitabine has significant potential as an effective therapy for pancreatic cancer by enhancing the effect of gemcitabine and overcoming chemoresistance. Further clinical studies in patients with pancreatic cancer are necessary to confirm our findings.

\section{References}

1. Burris HA III, Moore MJ, Andersen J, et al: Improvements in survival and clinical benefit with gemcitabine as first-line therapy for patients with advanced pancreas cancer: a randomized trial. J Clin Oncol 15: 2403-2413, 1997.

2. Demirezer LO, Kuruüzüm-Uz A, Bergere I, Schiewe HJ and Zeeck A: The structures of antioxidant and cytotoxic agents from natural source:anthraquinones and tannins from roots of Rumex patientia. Phytochemistry 58: 1213-1217, 2001.

3. Basu S, Ghosh A and Hazra B: Evaluation of the antibacterial activity of Ventilago madraspatana Gaertn., Rubia cordifolia Linn. and Lantana camara Linn.: isolation of emodin and physcion as active antibacterial agents. Phytother Res 19: 888-894, 2005.

4. Park MY, Kwon HJ and Sung MK: Evaluation of aloin and aloeemodin as anti-inflammatory agents in aloe by using murine macrophages. Biosci Biotechnol Biochem 73: 828-832, 2009.

5. Liu YX, Shen NY, Liu C and Lv Y: Immunosuppressive effects of emodin: an in vivo and in vitro study. Transplant Proc 41: 1837-1839, 2009.

6. Li J, Liu P, Mao H, Wanga A and Zhang X: Emodin sensitizes paclitaxel-resistant human ovarian cancer cells to paclitaxelinduced apoptosis in vitro. Oncol Rep 21: 1605-1610, 2009.

7. Ko JC, Su YJ, Lin ST, Jhan JY, Ciou SC, Cheng CM and Lin YW: Suppression of ERCC1 and Rad51 expression through ERK1/2 inactivation is essential in emodin-mediated cytotoxicity in human non-small cell lung cancer cells. Biochem Pharmacol 79: 655-664, 2010.

8. Chun-Guang W, Jun-Qing Y, Bei-Zhong L, Dan-Ting J, Chong W, Liang Z, Dan Z and Yan W: Anti-tumor activity of emodin against human chronic myelocytic leukemia K562 cell lines in vitro and in vivo. Eur J Pharmacol 627: 33-41, 2010.

9. Huang XZ, Wang J, Huang C, Chen YY, Shi GY, Hu QS and Yi J: Emodin enhances cytotoxicity of chemotherapeutic drugs in prostate cancer cells: the mechanisms involve ROS-mediated suppression of multidrug resistance and hypoxia inducible factor-1. Cancer Biol Ther 7: 468-475, 2008.

10. Olsen BB, Bjørling-Poulsen M and Guerra B: Emodin negatively affects the phosphoinositide 3-kinase/AKT signalling pathway: a study on its mechanism of action. Int J Biochem Cell Biol 39: 227-237, 2007.

11. Lu HF, Lai KC, Hsu SC, Lin HJ, Kuo CL, Liao CL, Yang JS, Chung JG: Involvement of matrix metalloproteinases on the inhibition of cells invasion and migration by emodin in human neuroblastoma SH-SY5Y cells. Neurochem Res 34: 1575-1583, 2009.

12. Kuo TC, Yang JS, Lin MW, Hsu SC, Lin JJ, Lin HJ, Hsia TC, Liao CL, Yang MD, Fan MJ, Wood WG and Chung JG: Emodin has cytotoxic and protective effects in rat C6 glioma cells: roles of Mdrla and nuclear factor kappaB in cell survival. J Pharmacol Exp Ther 330: 736-744, 2009. 
13. Adachi S, Kokura S, Okayama T, Ishikawa T, Takagi T, Handa O, Naito $\mathrm{Y}$ and Yoshikawa T: Effect of hyperthermia combined with gemcitabine on apoptotic cell death in cultured human pancreatic cancer cell lines. Int J Hyperthermia 25: 210-219, 2009.

14. Banerjee S, Kaseb AO and Wang Z: Antitumor activity of gemcitabine and oxaliplatin is augmented by thymoquinone in pancreatic cancer. Cancer Res 69: 5575-5583, 2009.

15. Chen J, Ouyang ZG, Zhang SH and Zhen YS: Down-regulation of the nuclear factor-kappaB by lidamycin in association with inducing apoptosis in human pancreatic cancer cells and inhibiting xenograft growth. Oncol Rep 17: 1445-1451, 2007.

16. Kunnumakkara AB, Guha S, Krishnan S, Diagaradjane $P$, Gelovani J and Aggarwal BB: Curcumin potentiates antitumor activity of gemcitabine in an orthotopic model of pancreatic cancer through suppression of proliferation, angiogenesis, and inhibition of nuclear factor-kappaB-regulated gene products. Cancer Res 67: 3853-3861, 2007.

17. Chuang SE, Yeh PY, Lu YS, Lai GM, Liao CM, Gao M and Cheng AL: Basal levels and patterns of anticancer drug-induced activation of nuclear factor- $\mathrm{kB}(\mathrm{NF}-\kappa \mathrm{B})$, and its attenuation by tamoxifen, dexamethasone, and curcumin in carcinoma cells. Biochem Pharmacol 63: 1709-1716, 2002.

18. Liptay S, Weber CK, Ludwig L, Wagner M, Adler G and Schmid RM: Mitogenic and antiapoptotic role of constitutive $\mathrm{NF}-\kappa \mathrm{B} / \mathrm{Rel}$ activity in pancreatic cancer. Int $\mathrm{J}$ Cancer 105: 735-746, 2003.

19. Wang W, Abbruzzese JL, Evans DB, Larry L, Cleary KR and Chiao PJ: The nuclear factor-kappa B RelA transcription factor is constitutively activated in human pancreatic adenocarcinoma cells. Clin Cancer Res 5: 119-127, 1999.

20. Greten FR, Weber CK, Greten TF, Schneider G, Wagner M, Adler G and Schmid RM: Stat3 and NF- $\kappa \mathrm{B}$ activation prevents apoptosis in pancreatic carcinogenesis. Gastroenterology 123: 2052-2063, 2002.

21. Arlt A, Gehrz A, Müerköster S, Vorndamm J, Kruse ML, Fölsch UR and Schäfer H: Role of NF-kappaB and Akt/PI3K in the resistance of pancreatic carcinoma cell lines against gemcitabine-induced cell death. Oncogene 22: 3243-3251, 2003.

22. Duxbury MS, Ito H, Zinner MJ, Ashley SW and Whang EE: Inhibition of SRC tyrosine kinase impairs inherent and acquired gemcitabine resistance in human pancreatic adenocarcinoma cells. Clin Cancer Res 10: 2307-2318, 2004.

23. El-Rayes BF, Shields AF, Vaitkevicius V and Philip PA Developments in the systemic therapy of pancreatic cancer. Cancer Invest 21: 73-86, 2003.
24. Fernández-Majada V, Aguilera C, Villanueva A, Vilardell F, Robert-Moreno A, Aytés A, Real FX, Capella G, Mayo MW, Espinosa L and Bigas A: Nuclear IKK activity leads to dysregulated notch-dependent gene expression in colorectal cancer. Proc Natl Acad Sci USA 104: 276-281, 2007.

25. Hernández-Vargas H, Rodríguez-Pinilla SM, Julián-Tendero M, Sánchez-Rovira P, Cuevas C, Antón A, Ríos MJ, Palacios J and Moreno-Bueno G: Gene expression profiling of breast cancer cells in response to gemcitabine: NF-kappaB pathway activation as a potential mechanism of resistance. Breast Cancer Res Treat 102: 157-172, 2007.

26. Dai Y, Pei XY, Rahmani M, Conrad DH, Dent P and Grant S: Interruption of the NF-kappaB pathway by Bay 11-7082 promotes UCN-01-mediated mitochondrial dysfunction and apoptosis in human multiple myeloma cells. Blood 103: 2761-2770, 2004.

27. Jiko M, Yano I, Sato E, Takahashi K, Motohashi H, Masuda S, Okuda M, Ito N, Nakamura E, Segawa T, Kamoto T, Ogawa O and Inui K: Pharmacokinetics and pharmacodynamics of paclitaxel with carboplatin or gemcitabine, and effects of CYP3A5 and MDR1 polymorphisms in patients with urogenital cancers. Int J Clin Oncol 12: 284-290, 2007.

28. Bentires-Alj M, Barbu V, Fillet M, Chariot A, Relic B, Jacobs N, Gielen J, Merville MP and Bours V: NF-kappaB transcription factor induces drug resistance through MDR1 expression in cancer cells. Oncogene 22: 90-97, 2003.

29. Fenig E, Nordenberg J, Beery E, Sulkes J and Wasserman L: Combined effect of aloe-emodin and chemotherapeutic agents on the proliferation of an adherent variant cell line of Merkel cell carcinoma. Oncol Rep 11: 213-217, 2004.

30. Kurokawa T, He G and Siddik ZH: Protein kinase inhibitors emodin and dichloro-ribofuranosylbenzimidazole modulate the cellular accumulation and cytotoxicity of cisplatin in a scheduledependent manner. Cancer Chemother Pharmacol 65: 427-436, 2010.

31. Lai GH, Zhang $\mathrm{Z}$ and Sirica AE: Celecoxib acts in a cyclooxygenase-2-independent manner and in synergy with emodin to suppress rat cholangiocarcinoma growth in vitro through a mechanism involving enhanced Akt inactivation and increased activation of caspases-9 and -3. Mol Cancer Ther 2: 265-271, 2003.

32. Banerjee S, Zhang Y, Ali S, Bhuiyan M, Wang Z, Chiao PJ, Philip PA, Abbruzzese J and Sarkar FH: Molecular evidence for increased antitumor activity of gemcitabine by genistein in vitro and in vivo using an orthotopic model of pancreatic cancer. Cancer Res 65: 9064-9072, 2005. 